Journal of Current and Advance Medical Research

January 2019, Vol. 6, No. 1, pp. 2-5

http://www.banglajol.info/index.php/JCAMR

ISSN (Print) 2313-447X

ISSN (Online) 2413-323X

NLM Catalog ID 101673828

DOI: https://doi.org/10.3329/jcamr.v6i1.40773

ORIGINAL ARTICLE

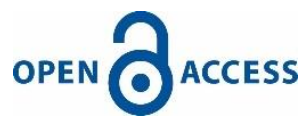

\title{
Anti-Inflammatory Effect of Ethanolic Extract of Carica Papaya Leaves and Indomethacin in Cotton Pellet Induced Granuloma in Animal Model
}

\author{
Afroza Sultana ${ }^{1}$, Rumana Afroz ${ }^{2}$, Onayza Yasmeen ${ }^{3}$, Muqbula Tasrin Aktar ${ }^{4}$, Md. Abdullah Yusuf ${ }^{5}$ \\ ${ }^{1}$ Assistant Professor, Department of Pharmacology, Mugda Medical College, Mugda, Dhaka, Bangladesh; ${ }^{2}$ Assistant Professor, \\ Department of Pharmacology, Dhaka Medical College, Dhaka, Bangladesh; ${ }^{3}$ Assistant Professor, Department of Pharmacology, Sir \\ Salimullah Medical College, Dhaka, Bangladesh; ${ }^{4}$ Assistant Professor, Department of Pharmacology, Shaheed Taj Uddin Medical \\ College, Gazipur, Bangladesh; ${ }^{5}$ Assistant Professor, Department of Microbiology, National Institute of Neurosciences \& Hospital, \\ Dhaka, Bangladesh
}

[Received on: 2 July 2018; Reviewed on: 30 October 2018; Accepted on: 19 November 2018; Published on: 1 January 2019]

\section{Abstract}

Background: Anti-inflammatory effect can be exerted by Carica papaya. Objective: The purpose of the present study was to see the anti-inflammatory effect of ethanolic extract of Carica papaya leaves and indomethacin in carrageenan induced rat paw edema animal model. Methodology: This was an animal study carried out in the Department of Pharmacology at Dhaka Medical College, Dhaka, Bangladesh during the period from July 2014 to June 2015 for a period of one (01) year. The leaves of Carica Papaya collected from Botanical garden, Mirpur, Dhaka, Bangladesh. The animals were divided into four groups. The animals were divided into four groups. In all the animals granuloma were induced by implantation of autoclaved cotton pellet on the 1st day and they treated as follows: Group I were served as control that was received normal saline. Group II were received ethanolic extract of Carica Papaya leaves. Group III were received ethanolic extract of Carica Papaya leaves. Group IV were received indomethacin. On the $15^{\text {th }}$ day animals were anesthetized, implanted pellets were dissected out, dried at hit air oven and the final weights were measured. Result: The experiment was carried out on 48 Long Evan Norwegian rats. Rats were divided in 4 groups of six animals each. The mean increase of weight of cotton pellet was $48.06 \pm 1.02$, $24.48 \pm 0.36,22.42 \pm 0.56$ and $18.02 \pm 0.43$ in group I, II, III and IV respectively. The inhibition of granuloma formation was $49.06 \%, 53.35 \%$ and $62.51 \%$ in group II, III and IV respectively. Conclusion: In conclusion the ethanolic extract of Carica Papaya leaves has effects on cotton pellet induced granuloma formation in experimental rat. [Journal of Current and Advance Medical Research 2019;6(1):2-5]

Keywords: Anti-Inflammatory effect; ethanolic extract; Carica papaya leaves; indomethacin; cotton pellet; granuloma; animal model

Correspondence: Dr. Afroza Sultana, Assistant Professor, Department of Pharmacology, Mugda Medical College, Mugda, Dhaka, Bangladesh; Email: afroza.moushumidr@gmail.com; Cell no.: +8801712822722

Cite this article as: Sultana A, Afroz R, Yasmeen O, Aktar MT, Yusuf MA. Anti-Inflammatory Effect of Ethanolic Extract of Carica Papaya Leaves and Indomethacin in Cotton Pellet Induced Granuloma in Animal Model. J Curr Adv Med Res 2019;6(1):2-5 Funding: This study has been performed without any funding from outside else.

Conflict of Interest: There was no conflict of interest to any of the authors.

Contributions to authors: Sultana A, Afroz R, have contributed in protocol preparation, data collection, data analysis upto the report writing; Yasmeen O, Aktar MT, Yusuf MA have prepared \& have revised the manuscript.

Copyright: @2019. Sultana et al. Published by Journal of Current and Advance Medical Research. This article is published under the Creative Commons CC BY-NC License (https://creativecommons.org/licenses/by-nc/4.0/). This license permits use, distribution and reproduction in any medium, provided the original work is properly cited, and is not used for commercial purposes. 


\section{Introduction}

Inflammation is tightly regulated by the body ${ }^{1}$. Little inflammation could lead to progressive tissue destruction by the harmful stimulus and compromise the survival of the organism. Chronic inflammation may lead to host diseases such as hay fever, atherosclerosis and even cancer ${ }^{2}$. The cell damage associated with inflammation acts on cell membrane to release leukocyte lysosomal enzymes; arachidonic acid is then liberated from precursor compounds, and various eicosanoids are synthesized $^{3}$. Cyclooxygenase pathway of arachidonate metabolism produces prostaglandins, which have a variety of effects on blood vessels and on cells involved in inflammation. The lipooxygenase pathway of arachidonate metabolism yields leukotrienes, which have a powerful chemotactic effect on eosinophils, neutrophils and macrophages and promote broncho-constriction and alteration in vascular permeability ${ }^{4}$.

Medicinal plants constitute an important natural wealth of a country ${ }^{5}$. They play a significant role in providing primary health care service to the rural people. According to WHO herbal medicine composed of medicinal plants that are still curing diseases of an estimated 3.5 billion people of the world as they can't afford western pharmacological drugs ${ }^{6}$.

Carica papaya have been used for medicinal purposes ${ }^{7}$. The leaves are used for treatment of fever, gonorrhea, syphilis, inflammation and as dressing for foul wounds ${ }^{8}$. However there are only few reports on the investigation into the biological activity of the dried leaf extract. The relative lack of information on the anti-inflammatory activity of Carica papaya leaves is the motivation of taking the issue as research. The purpose of the present study was to see the anti-inflammatory effect of ethanolic extract of Carica papaya leaves and indomethacin in carrageenan induced rat paw edema animal model.

\section{Methodology}

This was an animal study. This study was carried out at the Department of Pharmacology, Dhaka Medical College, Dhaka during the period from July 2014 to June 2015 for a period of one (01) year. The experiment was carried out on 48 Long Evan Norwegian rats. They were collected from the ICDDRB, Dhaka. The rats were of either sex, weighing between 130 to $160 \mathrm{gm}$. The rats were kept in the animal house of the Department of Pharmacology at Dhaka Medical College, Dhaka, Bangladesh. Rats of different groups were kept in different metallic cages. They were allowed to feed on standard laboratory diet and to drink water ad libitum. The plant material i.e. leaves of Carica Papaya collected from Botanical garden, Mirpur, Dhaka, Bangladesh. The plant was authenticated by National Herbarium, Dhaka and a voucher specimen was deposited. A voucher number was obtained. The voucher number of it is 41888 . The leaves of Carica Papaya were cut into pieces shade-dried and grounded to coarse powder and then supplied to "Centre for Advanced Research in Sciences (CARS)", University of Dhaka for making ethanolic extract. At CARS the leaves of Carica Papaya was soaked in Ethanol (800) ml with continuous shaking at 25.C for 3 days and filtered. The organic extract was evaporated under vacuum to obtain a semisolid residue $(4.1 \mathrm{gm})$. Indomethacin powder was collected from Novartis pharmaceutical.

Cotton pellet induced granuloma animal model: This is an established animal model to screen the chronic anti-inflammatory activity of the drugs. One sterile cotton pellet weighing $30 \mathrm{mg}$ each was implanted subcutaneously in one groin region of each rat. Rats were fed with the respective drug daily for 14 days along with free access to water and food ad libitum. Later on the 15th day animals were anesthetized, the cotton pellets were removed, cleaned of the extraneous tissue and dried in a hot air oven to a constant weight and the dry weight of pellets were determined. The dry weight of the granuloma was calculated by noting the difference in the dry weight of the cotton pellets recorded before and after implantation. The percentage change of granuloma weight relative to control group was taken as an index of chronic antiinflammatory activity. It was calculated by Percent inhibition $=100 \mathrm{X}(1-\mathrm{Wt} / \mathrm{Wc})$. Where, $\mathrm{Wt}=$ difference in pellet weight in drug treated group. $\mathrm{Wc}=$ difference in pellet weight in drug untreated group.

Cotton pellet induced inflammatory granuloma: The animals were divided into four groups. In all the animals granuloma were induced by implantation of autoclaved cotton pellet on the 1st day and they treated as follows: Group I consisted of 6 rats and were served as control that was received normal saline in a volume of $0.6 \mathrm{ml}$ orally daily for 14 days. Group II consisted of 6 rats and were received ethanolic extract of Carica papaya leaves at a dose of $50 \mathrm{mg} / \mathrm{kg}$ body weight orally daily for 14 days. Group III consisted of 6 rats and were received ethanolic extract of Carica papaya leaves at a dose of $100 \mathrm{mg} / \mathrm{kg}$ body weight orally daily for 14 days. Group IV consisted of 6 rats and 
were received indomethacin at a dose of $5 \mathrm{mg} / \mathrm{kg}$ body weight orally daily for 14 days. On the 15 th day animals were anesthetized, implanted pellets were dissected out, dried at hit air oven and the final weights were measured.

Statistical Analysis: All the results have been expressed as mean plus/minus standard error of mean (mean \pm SEM). Significance of difference between groups were assessed by using student's $t$ test with $\mathrm{P}<0.05$ considered as being significant.

\section{Result}

The chronic inflammation was induced by implanting one autoclaved cotton pellet weighing $30 \mathrm{mg}$ subcutaneously at the groin region of each rat. The day of implantation was counted as day 1 and on the 15th day animals were anesthetized and cotton pellet with granulation tissue were dissected out, cleaned of extraneous tissue and dried in a hot air oven to a constant weight and the dry weight of the pellets were determined. The weights were $78.14 \pm 1.0 \mathrm{mg}, 54.60 \pm 0.36 \mathrm{mg}, 52.58 \pm 0.36 \mathrm{mg}$ and $48.14 \pm 0.30 \mathrm{mg}$ for group I, II, III, IV respectively. In the study the mean initial weight of cotton pellets were $30.08 \pm .02 \mathrm{mg}, 30.12 \pm 0.04 \mathrm{mg}, 30.16 \pm 0.03$ $\mathrm{mg}$, and $30.12 \pm 0.02 \mathrm{mg}$ for group I, II, III and IV respectively. The increase in weight of pellets of ethanolic extract of Carica Papaya leaves 50 $\mathrm{mg} / \mathrm{kg}$, ethanolic extract of CP $100 \mathrm{mg} / \mathrm{kg}$ and indomethacin $5 \mathrm{mg} / \mathrm{kg}$ body weight, treated group were $24.48 \pm 0.36 \mathrm{mg}, 22.42 \pm 0.56 \mathrm{mg}$ and 18.02 $\pm 0.43 \mathrm{mg}$ respectively. Where the increase in weight of pellet in control group was $48.06 \pm 1.02$ mg. The percentage inhibition of granuloma formation were $49.06 \%, 53.35 \%$ and $62.51 \%$ as compared to control, in ethanolic extract of CP 50 $\mathrm{mg} / \mathrm{kg}$, ethanolic extract of $\mathrm{CP} 100 \mathrm{mg} / \mathrm{kg}$ and indomethacin $5 \mathrm{mg} / \mathrm{kg}$ treated groups respectively (Table 1).

Table 1: Effects of ethanolic extract of Carica Papaya leaves, Indomethacin on cotton pellet induced granuloma

\begin{tabular}{|l|c|c|c|c|c|}
\hline Group & $\begin{array}{l}\text { Number } \\
\text { of rats }\end{array}$ & $\begin{array}{l}\text { Initial weight of } \\
\text { cotton pellet } \\
\text { (mean } \pm \text { SEM) }\end{array}$ & $\begin{array}{l}\text { Final weight of } \\
\text { cotton pellet } \\
\text { (mean } \pm \text { SEM) }\end{array}$ & $\begin{array}{l}\text { Increase in weight } \\
\text { of cotton pellet } \\
\text { (mean } \pm \text { SEM) }\end{array}$ & $\begin{array}{l}\text { Inhibition of } \\
\text { granuloma } \\
\text { formation \% }\end{array}$ \\
\hline Group I & 6 & $30.08 \pm 0.02$ & $78.14 \pm 1.0$ & $48.06 \pm 1.02$ & \\
\hline Group II & 6 & $30.12 \pm 0.04$ & $54.60 \pm 0.36$ & $24.48 \pm 0.36 *$ & $49.06 \%$ \\
\hline Group III & 6 & $30.16 \pm 0.03$ & $52.58 \pm 0.36$ & $22.42 \pm 0.56 *$ & $53.35 \%$ \\
\hline Group IV & 6 & $30.12 \pm 0.02$ & $48.14 \pm 0.30$ & $18.02 \pm 0.43 * *$ & $62.51 \%$ \\
\hline
\end{tabular}

$* \mathrm{P}<0.05$ in a test of significance difference from control; $* * \mathrm{P}<0.001$ in a test of significance difference from control; Group I : 0.6 $\mathrm{ml}$ normal saline orally and served as control; Group II : Ethanolic extract of Carica Papaya $50 \mathrm{mg} / \mathrm{kg}$ body weight orally; Group III : Ethanolic extract of Carica Papaya $100 \mathrm{mg} / \mathrm{kg}$ body weight orally; Group IV : Indomethacin 5mg/kg body weight orally

\section{Discussion}

Neutrophils also provide additional killing activities by releasing antimicrobial peptides and proteins, such as defensins, cathelicidin and iron binding proteins $^{9}$. Neutrophils also release cytokines including IL-1, IL-6, TNF- $\alpha$, interferon $\gamma$ and others. Such pro-inflammatory cytokines in turn induce the liver to synthesize various acute phase reactant proteins and also produce systemic inflammatory responses like fever, leukocytosis. The present study was carried out to evaluate the anti-inflammatory effect of ethanolic extract of Carica papaya leaves. Its anti-inflammatory effects were tested on Long Evan Norwegian rats.

In the present work chronic inflammation was induced. Chronic inflammation was induced by implanting one autoclaved cotton pellet weighing $30 \mathrm{mg}$ subcutaneously on one groin region of each rat. The day of implantation was counted as day 1 and on the $15^{\text {th }}$ day the animals were anesthetized and cotton pellets with granulation tissues were dissected out. In this study, concomitant administration of ethanolic extract of Carica Papaya leaves and non-steroidal anti-inflammatory drug one hour before carrageenan injection and daily for 14 days reduced rat paw edema and weight of granulation tissue. The reduction of rat paw edema and weight of granulation tissue was statistically significant in comparison to control group.

Papaya when consumed regularly will ensure a good supply of vitamin $\mathrm{A}$ and $\mathrm{C}$, which are essential for eyesight and can prevent early age blindness in children ${ }^{10}$. The fruit is a rich source for different types of enzymes. Papain, vegetable pepsin present in good amount in unripe fruit is an excellent aid to digestion, which helps to digest the protein in food at acid, alkaline or neutral medium $^{11}$. Thus it can be prescribed for dyspeptic patients, as papain may help in the digestion of proteins. The fermented papaya fruit is a promising 
antioxidant. It improves the antioxidant defensive power in elderly patients. Ripe and unripe papaya produce significant antibacterial activity against $S$. aureous, B. cereus, E. coli, P. aeruginosa and Sh. Flexneri. They also inhibit the growth of B. cereus, E. coli, S. faecalis, S. aureus, P. vulgaris and Sh. flexneri. The active ingredients of papaya is flavonoid which is responsible for antibacterial activity of papaya ${ }^{12}$. Besides, cysteine proteinases, papain, chymopapain, caracian and glycyl endopeptidase are other bioactive compounds of papaya ${ }^{13}$. It also has remarkable antiparasitic, hepatoprotective, antioxidant and wound-healing effect ${ }^{14}$. Its fruit is also used in cosmetics for healthy skin complexion. The unripe fruit is also laxative and diuretic.

Cotton pellet granuloma is the most suitable method for studying the efficacy of drugs against proliferative phase of inflammation which by subcutaneous implantation of cotton pellets ${ }^{15}$. The dry weight of pellets correlates well with the amount of granulomatous tissue ${ }^{16}$. The extract of Carica papaya produced significant inhibition of granulomatous tissue formation. This indicates that the extract can inhibit chronic inflammation in which various types of cellular migration are involved $^{17}$.

The present study provides an initial step in demonstrating the anti-inflammatory effect of ethanolic extract of Carica papaya leaves. The obtained data support the basis for future use of ethanolic extract of Carica papaya in traditional system of medicine. The results obtained in this experiment may not represent the exact effect. Despite all these limitations, interpretation of the results obtained in this study was made carefully and cautiously.

\section{Conclusion}

In conclusion, this study has established the antiinflammatory effect of ethanolic extract of Carica papaya leaves by showing the changes of cotton pellet granuloma induced by it. Further basic and clinical studies are required in order to identify the exact active ingredient, determine the precise mechanism of action and to examine the toxicity of the extract.

\section{References}

1. Abdullah M, Chai PS, Loh CY, Chong MY, Quay HW, Vidyadaran S, et al. Carica papaya increases regulatory $\mathrm{T}$ cells and reduces IFN- $\gamma+\mathrm{CD} 4+\mathrm{T}$ cells in healthy human subjects. Molecular Nutrition Food Research 2011;55(5):803-6

2. El Moussaoui A, Nijs M, Paul C, Wintjens R, Vincentelli J, Azarkan M, et al. Revisiting the enzymes stored in the laticifers of Carica papaya in the context of their possible participation in the plant defence mechanism. Cellular Molecular Life Sciences 2001;58(4):556-70

3. Krishna KL, Paridhavi M, Patel JA. Review on nutritional, medicinal and pharmacological properties of Papaya (Carica papaya Linn.). NPR 2008;7(4):364-373

4. Nayak BS, Pereira LP, Maharaj D. Wound healing activity of Carica papaya L. in experimentally induced diabetic rats. IJEB 2007;45(8):739-743

5. Hounzangbe-Adote MS, Paolini V, Fouraste I, Moutairou K, Hoste H. In vitro effects of four tropical plants on three lifecycle stages of the parasitic nematode, Haemonchus contortus. Research in Veterinary Science. 2005;78(2):155-60

6. Rajkapoor B, Jayakar B, Kavimani S, Murugesh N. Effect of dried fruits of Carica papaya Linn on hepatotoxicity. Biological Pharmaceutical Bulletin. 2002;25(12):1645-6

7. Mikhalchik EV, Ivanova AV, Anurov MV, Titkova SM, Penkov LY, Kharaeva ZF, Korkina LG. Wound-healing effect of papaya-based preparation in experimental thermal trauma. Bulletin of Experimental Biology and Medicine. 2004;137(6):560-2

8. Salvemini D, Wang ZQ, Bourdon DM, Stern MK, Currie MG, Manning PT. Evidence of peroxynitrite involvement in the carrageenan-induced rat paw edema. European journal of pharmacology. 1996;303(3):217-20.

9. Swingle KF, Shideman FE. Phases of the inflammatory response to subcutaneous implantation of a cotton pellet and their modification by certain antiinflammatory agents. J Pharm Experi Therap 1972;183(1):226-34

10. Owoyele BV, Adebukola OM, Funmilayo AA, Soladoye AO. Anti-inflammatory activities of ethanolic extract of Carica papaya leaves. Inflammopharmacology. 2008;16(4):168-73

11. Vij T, Prashar Y. A review on medicinal properties of Carica papaya Linn. Asian Pacific J Trop Dis 2015;5(1):1-6

12. Milind P, Gurditta G. Basketful benefits of Papaya. Intern Res J Pharm 2011;2(7):6-12

13. Elgadir MA, Salama M, Adam A. Carica Papaya as a Source of Natural Medicine and Its Utilization in SelectedPharmacetical Applications. Int J Pharm Pharm Sci. 2014;6(1):880-4

14. Lohiya NK, Mishra PK, Pathak N, Manivannan B, Bhande SS, Panneerdoss S, Sriram S. Efficacy trial on the purified compounds of the seeds of Carica papaya for male contraception in albino rat. Reprod Tox 2005;20(1):135-48 15. Nayeem K, Gupta D, Nayana H, Joshi RK. Antiurolithiatic potential of the fruit extracts of Carica papaya on ethylene glycol induced urolithiatic rats. J Pharm Res. 2010;3:2772-5

16. Patil T, Patil S, Patil A, Patil S. Carica papaya leaf extractsAn Ethnomedicinal boon. Intern J Pharmacog Phytochem Res 2014;6(2):260-5

17. Ezike AC, Akah PA, Okoli CO, Ezeuchenne NA, Ezeugwu S. Carica papaya (Paw-Paw) unripe fruit may be beneficial in ulcer. J Med Food 2009;12(6):1268-73 